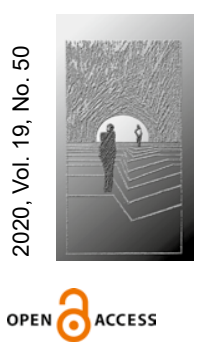

\title{
Godność osobista w ocenie młodzieży - analiza teoretyczno-empiryczna
}

\section{STRESZCZENIE}

CEL NAUKOWY: Celem artykułu jest odtworzenie i pokazanie świadomości godnościowej młodzieży w aspekcie jej doświadczeń w różnych sytuacjach życiowych.

PROBLEM I METODY BADAWCZE: Przedstawiony problem badawczy dotyczy odpowiedzi na pytanie, jak badani rozumieją godność osobistą człowieka, jak oceniają wybitne jednostki o wysokim poziomie godności nabytej. Podstawą do rozważań empirycznych są wyniki badań jakościowych zrealizowanych w latach 2017-2018 wśród różnych kategorii młodzieży uczącej się lub studiującej.

PROCES WYWODU: Odwołując się do opracowań naukowych, dokonano interdyscyplinarnej refleksji nad rozumieniem pojęcia godność i skonfrontowano wyniki z opiniami badanych.

WYNIKI ANALIZY NAUKOWEJ: Z przeprowadzonych badań jakościowych wynika, że około $60 \%$ badanych deklaruje pozytywne - niekiedy ogólnikowe - oceny o ludziach charakteryzujących się wysokim poczuciem godności własnej. Tylko co dziesiąty badany wyrażał negatywne oceny o takich osobach. Niektórzy ankietowani mieli trudności z podaniem bliższych określeń, czym jest godność osobista, lub uważali to pojęcie za niedefiniowalne.

WNIOSKI, INNOWACJE, REKOMENDACJE: W sytuacji, gdy wielu ludzi traci właściwe poczucie godności osobistej, postulat budzenia poczucia godności i jej poszanowania staje się wyzwaniem i zadaniem edukacyjnym dla wszystkich podmiotów interakcji w procesach wychowawczych i dydaktycznych.

$\rightarrow$ SŁOWA KLUCZOWE: GODNOŚĆ OSOBISTA, SZACUNEK, MORALNOŚĆ, WARTOŚCI, MŁODZIEŻ

\section{ABSTRACT}

Personal dignity in the assessment of youth - theoretical and empirical analysis

RESEARCH OBJECTIVE: The purpose of the paper is to recreate and show the dignity awareness of young people in the aspect of their experiences in various life situations. 


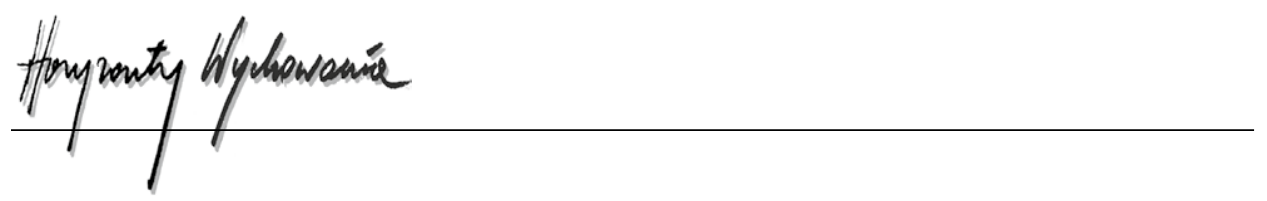

THE RESEARCH PROBLEM AND METHODS: The presented research problem concerns the answer to the question of how the respondents understand the personal dignity of a person, how they evaluate outstanding individuals with a high level of acquired dignity. The basis for empirical considerations are the results of qualitative research carried out in 2017-2018 among various categories of young people.

THE PROCESS OF ARGUMENTATION: Referring to scientific studies, an interdisciplinary reflection was made on the understanding of the concept of dignity and the results were confronted with the opinions of the respondents.

RESEARCH RESULTS: Qualitative research shows that about $60 \%$ of respondents declare positive - sometimes vague - assessments of people with a high sense of self-esteem. Only every tenth respondent expressed negative opinions about such people. Some respondents had difficulty giving closer definitions of what personal dignity is or considered the concept indefinable.

CONCLUSIONS, INNOVATIONS, AND RECOMENDATIONS: In a situation where many people lose the proper sense of personal dignity, the postulate of awakening the sense of dignity and respect it becomes a challenge and an educational task for all subjects of interaction in educational and didactic processes.

\section{$\rightarrow$ KEYWORDS: PERSONAL DIGNITY, RESPECT, MORALITY, VALUES, YOUTH}

Osoba ludzka i związana z nią godność jest nie tylko dana, ale i zadana z możliwością rozwoju. Godność człowieka wymaga, aby działał on w sposób świadomy i wolny. O ile godność osobowa jest wartością wynikającą z racji bycia osobą, to godność osobista (własna) jest właściwością indywidualną i specyficzną, właściwą każdej jednostce, nadbudowuje się ona poniekąd na godności osobowej. W przeciwieństwie do godności osobowej ta godność podlega zmienności historycznej i społecznej. Jej rozwój zależy od aspiracji jednostki i jej wrażliwości na wartości. Skala wyznawanych wartości oraz stopień ich akceptacji wzmacnia własne poczucie godności nie tylko przez siebie, ale i przez innych. Godność osobista (jej poczucie) może ulec zachwianiu lub utracie, gdy okaże się, że działalność jednostki była manipulowana przez nadrzędny czynnik w imię sprzecznych lub negatywnych wartości i celów przez nią wyznawanych. Aby żyć godnie, trzeba być sobą, zachowywać wierność wobec siebie oraz odnosić się z szacunkiem do drugich (godność jest wzajemnością) (por. Piluś, 1999, s. 72).

Godność osobista jest pewnym doświadczeniem wewnętrznym, które można by określić jako swoisty element samowiedzy. Takie poczucie godności kształtuje się i ujawnia w relacjach międzyludzkich. To poczucie godności wiąże się z odczuciem granic, jakie człowiek wyznacza sobie sam w interakcji i jakie wyznacza partnerowi interakcji.

Każdy posiada taką samowiedzę, że przekroczenie pewnej określonej granicy przez partnera będzie oznaczało urażenie jego godności, jak też wiedzę, że nie może postąpić w określony sposób (np. poniżyć się, błagać o uzyskanie jakiegoś uczucia czy dobra itp.), 
bo to także uwłaczało będzie jego godności. Oczywiście "granica” ta jest uwarunkowana doświadczeniem kulturowym i osobistym, które wytyczają jej zasięg, jednakże każdy człowiek jakąś tę granicę posiada (Nowicka-Kozioł, 2002, s. 11).

Na płaszczyźnie psychologicznej godność ludzka jest interpretowana jako całościowa, zintegrowana i dynamiczna struktura mentalna, opierająca się na relacji „ja” do samego siebie, jest pozytywnie wartościującą relacją do własnej osoby i grupy.

\begin{abstract}
Świadomość towarzysząca spełnianiu własnych aktów, samoocena „ja”, poczucie własnej wartości są istotą tej godności. Jej posiadanie rzutuje na przeżywanie, postawę człowieka i jego działanie. Psychologia opisuje godność osobowościową jako postawę, indywidualną cechę charakteru moralnego człowieka, która motywuje i determinuje jego postępowanie, styl życia, wrażliwość moralną zgodnie z przyjmowanym system wartości. Zasadniczą rolę w poczuciu własnej godności odgrywają takie czynniki, jak: charakter moralny jednostki, aktywna postawa, wolność wewnętrzna, podmiotowość i odpowiedzialność. Godność integruje osobowość człowieka (w wymiarze społecznym i indywidualnym), motywuje do działania i określa sposób zaspokajania przez niego potrzeb, pozytywnie wpływając na życiowe wybory (Stępień, 2016, s. 380).
\end{abstract}

W dalszych rozważaniach opiszemy teoretycznie pojęcie godności osobistej rozumianej jako poczucie godności własnej, a następnie próbujemy odtworzyć i opisać świadomość godnościową młodzieży w aspekcie jej doświadczeń w różnych sytuacjach życiowych. Godność ludzką analizujemy z socjologicznego punktu widzenia. Ujmujemy to zagadnienie moralne jakby „od dołu”, tzn. w aspekcie świadomości młodzieży polskiej. Usiłujemy w tych analizach odpowiedzieć tylko na jedno pytanie, a mianowicie, jak badani rozumieją godność osobistą człowieka, jak oceniają wybitne jednostki o wysokim poziomie godności nabytej.

Podstawą do rozważań empirycznych są wyniki badań jakościowych zrealizowanych w latach 2017-2018 wśród różnych kategorii młodzieży uczącej się lub studiującej. Badania socjologiczne przeprowadzono zasadniczo w trzech środowiskach akademickich: Wyższej Szkoły Nauk Społecznych z siedzibą w Lublinie (studenci socjologii, psychologii i pracy socjalnej), Katolickiego Uniwersytetu Lubelskiego Jana Pawła II (studenci pedagogiki) i Uniwersytetu Warmińsko-Mazurskiego w Olsztynie (studenci Wydziału Bioinżynierii Zwierząt i Wydziału Nauk Społecznych) oraz wśród młodzieży szkół średnich w Stalowej Woli. W sumie zebrano 165 - mniej lub bardziej obszernych - wypowiedzi (65\% kobiet i 35\% mężczyzn). Badania ankietowe - na moją prośbę - przeprowadzili doktoranci z Instytutu Pedagogiki KUL oraz dr hab. Agnieszka Zduniak z Uniwersytetu Warmińsko-Mazurskiego w Olsztynie.

\title{
1. Godność osobista - analiza teoretyczna
}

Godność osobista nie przysługuje automatycznie każdemu człowiekowi jako takiemu, nie jest traktowana jako walor wspólny wszystkim ludziom, lecz jako stopniowalne poczucie godności, charakteryzujące w zróżnicowany sposób jednostki ludzkie. Jest cechą 


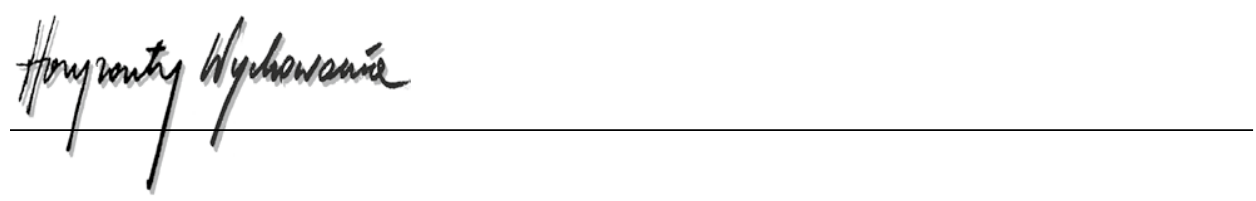

charakteru (postawa). Pojawia się zarówno wtedy, gdy sami nie czynimy niczego, co uwłacza godności innych, jak i wtedy, gdy nie godziny się na poniżanie naszej godności. W obydwu przypadkach staramy się „zachować twarz”. Godność w tym znaczeniu nie jest kategorią normatywną, lecz opisową, i jest przedmiotem badań psychologicznych i socjologicznych. W ujęciu psychologicznym i społecznym godność jest w pewnym sensie funkcją kształtowania się świadomości i zawiera w sobie element potencjalności. Każdy może być świadomy w większym lub mniejszym stopniu swej godności. Może ją odpowiednio udoskonalać, rozwijać, kształtować i dopełniać, może ją także utracić (por. Mariański, 2014, s. 167-177).

Według psychologicznej i socjologicznej interpretacji idei godności (immanentna, osobowościowa, osobista, nieegalitarna, relatywna) są tacy, którzy ją mają, i tacy, którzy jej nie mają. Nie przysługuje ona każdemu człowiekowi bez wyjątku i w jednakowym stopniu. Człowiek w tej koncepcji wykazuje się godnością lub nie wykazuje, w zależności od swoich cech i od indywidualnego sposobu postępowania, a także od warunków zewnętrznych o charakterze obiektywnym. Godność ta rozwija się podobnie jak i inne właściwości człowieka. W sytuacjach osobistego zagrożenia człowiek traci swą godność, utrzymuje ją lub nawet odzyskuje. Odnosząc zwycięstwo w czasie próby, zyskuje szacunek moralny na długi czas, przegrywając, podlega deprecjacji moralnej w swoich odczuciach i w ocenie otoczenia społecznego (por. Ossowska, 1983, s. 519-522, 559).

Człowiek o wysokiej godności osobowościowej i osobistej żyje zgodnie z wartościami moralnymi, stara się nie wykraczać poza wyznaczone granice i zasługuje na szacunek ze strony innych ludzi.

Osoby z wysokim poczuciem własnej wartości nie tylko są szczęśliwsze, ale też lepiej i wydatniej pracują, wywierają pozytywny wpływ na inne osoby z otoczenia, są twórczy i przedsiębiorczy. Jeśli natomiast w swoich oczach nie mamy za wysokiej wartości, nie cenimy się i nie wierzymy w siebie, to czujemy się niekochani, mało warci, niezdolni do niczego. Nie potrafimy zatroszczyć się o innych, a często także o siebie. Nasze działania sprowadzają się do biadolenia i użalania się nad sobą (Furmanek, 2013, s. 176).

Ludzie o niskim poczuciu własnej wartości nie wierzą w siebie i we własne siły. Nie potrafią podjąć wyzwań w obawie przed porażką czy ryzykiem. Jest im trudniej żyć.

Godność osobista nie jest czymś, co się ma lub nosi w sobie jako stałe wyposażenie natury, lecz stanowi rezultat tworzenia (konstrukt) na płaszczyźnie osobowościowej i międzyludzkiej kooperacji. Poczucie godności jest stopniowalne na poziomie struktury płytkiej, a między formami ekstremalnymi istnieje wiele stopni pośrednich. Godność w ujęciu psychospołecznym to szczególna wartość człowieka jako osoby pozostającej $w$ relacjach interpersonalnych, uzasadniających i usensowniających życie osobowe, a także pozytywnie wartościująca relacja do własnej osoby i grupy społecznej, z którą jednostka się identyfikuje.

Konstytuującym komponentem tego ustosunkowania się jest samoocena polegająca na przeżywaniu swej wartości. Motywuje ona do zachowań moralnie wartościowych, uodparnia na wszelkie formy manipulacji i zniewolenia oraz wpływa na radzenie sobie 
w trudnych sytuacjach. Godność zakłada poczucie wewnętrznej wolności, podmiotowości i odpowiedzialności. O ile godność osobowa (ontologiczna) jest nieutracalna, to godność osobista i osobowościowa zdobywana jest własnym wysiłkiem, przede wszystkim moralnym, pod wpływem dążenia do doskonałości własnej. Poczucie godności może być zdeformowane przez absolutyzowanie jakiegoś jej elementu składowego (zdolności, urody, majątku, stanowiska), kształtowanie się egocentryzmu i grupowego szowinizmu, ale i przez zaniżanie poczucia własnej wartości, dewiacje w życiu moralnym (por. Chlewiński i Zaleski, 1989).

Człowiek chce osiągnąć w życiu określone efekty, to jest związane z uznawanymi przez niego wartościami. Realizacja tych wartości wpływa na kształt poczucia godności własnej. Wytworzenie się poczucia własnej wartości jest efektem długotrwałego procesu. Na jego przebieg wpływa wiele czynników. Najważniejszym jest oddziaływanie wychowawcze na dziecko w jego najbliższym otoczeniu społecznym. Początkowo to, jak człowiek wartościuje siebie, zależy od tego, jak wartościują go inni.

\begin{abstract}
Poczucie własnej wartości jest nierozerwalnie związane z potrzebą osiągnięć, która pełni w stosunku do niego funkcję usługową, ponieważ wszystkie działania z niej wynikające służą utrzymaniu poczucia wartości. Dlatego też istnieje drugi ważny rodzaj relacji: aspiracje i poczucie własnej wartości. W naszej tradycji kulturowej człowiek ambitny, to jednostka twórcza, o silnie zaznaczonym osobowym systemie wartości, konsekwentnie realizująca cele, $z$ dużym poczuciem własnej wartości. Człowiek ambitny budzi szacunek, a także odczuwa szacunek dla samego siebie. Wiąże się to z pozytywną samooceną i samoakceptacją (Konarska, 2003, s. 84).
\end{abstract}

Wyłaniająca się i kształtująca się godność osobista dotyczy także tego, na czym nam zależy w życiu, pozwala nam reagować na różne sprawy w kontekstach sytuacyjnych i w działaniach tak, aby zmieniać świat. Poczucie własnej wartości może się zawierać w określonych naszych planach, np. zrobienie kariery czy założenie rodziny, a ich sukces lub niepowodzenie prowadzi do podniesienia osobistej wartości lub jej obniżenia. Jeżeli zainwestowaliśmy siebie w jakieś społeczne projekty, wówczas jesteśmy emocjonalnie podatni na społeczne oceny normatywne odnoszące się do sposobu, w jaki wykonujemy związane z nim role. Nasze własne definicje określające to, które z ocen normatywnych są dla nas wystarczająco ważne, konstytuuje nasze poczucie własnej wartości. Margaret S. Archer stwierdza krótko: ,jesteśmy tym, na czym nam zależy” (Archer, 2017, s. 141).

Poczucie godności opiera się na dwóch podstawach: psychologicznej i antropologicznej. W aspekcie psychologicznym tworzymy pozytywną koncepcję siebie, gromadzimy doświadczenia sukcesów, a unikamy porażek, jesteśmy uwrażliwieni na błędy i krytykę, podejmujemy różne działania celem pozytywnej autoprezentacji. Druga podstawa poczucia godności wyraża się przekonaniem, że osoba ludzka jest bytem szczególnym i z tego tytułu przysługuje jej godność. Posiadana godność wyklucza zachowania niegodne, polegające na instrumentalnym traktowaniu siebie lub drugiego człowieka, czy używaniu siebie lub kogoś jako środka do celu, a nie jako celu samego w sobie (por. Oleś, 2012, s. 94). 


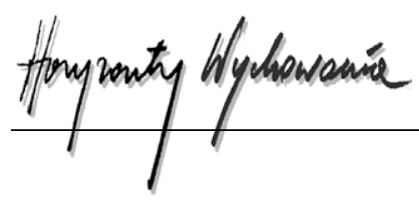

Poczucie godności ujawnia się w sposób szczególny w określonych sytuacjach. Piotr K. Oleś wymienia m.in. następujące sytuacje: a) podejmowanie ważnych decyzji życiowych związanych z edukacją, pracą, zawarciem małżeństwa; b) zaangażowanie w realizację celów, które mają wyraźne zakotwiczenie aksjologiczne, i wiążą się z przekonaniem, że człowiek spełnia coś bardzo ważnego i wartościowego; c) kierowanie się podstawowym zaufaniem i szacunkiem dla drugiego człowieka, np. w sytuacji wybaczenia komuś lub odrzucenia pokusy uczynienia czegoś niegodziwego; d) uczestniczenie w sytuacjach podniosłych i związanych z wartościami wyższymi o charakterze religijnym, duchowym, moralnym, estetycznym czy poznawczym (por. Oleś, 2012, s. 96).

Zjawiska związane z poczuciem godności nie układają się symetrycznie.

Asymetria poczucia godności polega po pierwsze na znacznie łatwiejszym rozpoznawaniu jej w odniesieniu do siebie niż w odniesieniu do innych: świadomość naruszania cudzej godności jest na ogół znacznie słabsza od wyczulenia na naruszanie godności własnej przez innych ludzi. Po drugie, asymetria poczucia godności polega na łatwiejszym uświadamianiu sobie jej zagrożeń niż szans jej podtrzymania: wrażliwość na własnym punkcie i wynikająca z niej urażona duma jest na ogół znacznie łatwiejsza do wywołania od wrażliwości na te sytuacje i okoliczności, które pozwalają poczucie godności zademonstrować lub wyrazić (Oleś, 2012, s. 93).

Godność osobista jest niekiedy rozumiana szerzej, nie tylko jako poczucie własnej wartości, ale i jako postawa lub cecha charakteru (godność osobowościowa). Odnosi się ona wtedy do osoby jako kierującej się w życiu wyznawanym systemem wartości, ideałów i potrafiącej bronić swoich racji niezależnie od konsekwencji. Taka postawa zakłada pewną dozę krytycyzmu wobec siebie i innych ludzi oraz otwartości na to, co nowe i godne uznania. Jako postawa i cecha charakteru godność jest historycznie zmienna, niekiedy jest utożsamiana ze sprawowanymi znaczącymi rolami społeczno-zawodowymi (godnościami) i jako taka jest bliska pojęciu honoru. Niektórzy badacze wiążą godność osobistą człowieka z problemem jego podmiotowości. Podmiotowość jako atrybut ludzkiej istoty wiąże się z kształtowaniem indywidualnego „ja”, dokonywaniem indywidualnych wyborów (nawet wbrew naciskom z zewnątrz), stawianiem sobie pytań o treść i sens własnego życia. Chodzi tu nie tylko o wierność sobie, o potwierdzenie siebie, ale i o uwiarygodnienie własnych wartości (por. Gajda, 2013, s. 134-136).

Człowiek o wysokim poczuciu godności, pozytywnie oceniający siebie, zazwyczaj także szanuje godność innych.

Godność człowieka warunkuje w dużym stopniu poczucie jego własnej wartości. Osobnik o wysokim poczuciu swojej wartości, w tym godności, nie posunie się nigdy do czynów hańbiących go. Będzie też wolał przymierać głodem niż żebrać o pomoc. Nie będzie narzekał na los i, zgodnie z predyspozycjami, podejmie próby samorealizowania się w świecie wartości wyższych - w sztuce, nauce, pracy dla innych; będzie tworzył zgodnie z wymogami dobra i piękna. Wysoka jakość życia oznacza w kategoriach subiektywnych spełnienie potrzeb i uzyskanie względnej harmonii w godzeniu życia prywatnego i publicznego z obowiązkami bytowania i pragnieniami; w kategoriach obiektywnych oznacz życie 
zgodne z akceptowanymi normami społecznymi, życie zaangażowane i godziwe (Gajda, 2013, s. 150).

Godność jako poczucie wiąże się zawsze z jakimś doświadczeniem wewnętrznym.

Godność osobowościowa i osobista ma charakter dynamiczny, jest niemal ustawicznie in statu fieri. Staje się - w pewnym sensie - wartością nabywaną, proporcjonalną do „zasług” człowieka, będącą efektem starań o jej zdobywanie z pomocą innych ludzi. Paweł Prüfer nazywa ten typ godności „godnością merytokratyczną” (Prüfer, 2017, s. 290). Jest wartością, którą człowiek może nabyć, rozwijać ją, a nawet utracić, przez niemoralne zachowania lub inne okoliczności. Człowiek żyjący z godnością, mający poczucie własnej wartości, potrafi tę godność rozwijać oraz wzbudzać u innych poważanie i szacunek.

Od strony treściowej poczucie godności i postawa godnościowa nie jest wielkością stałą, zmienia się w zależności od warunków historycznych i społeczno-kulturowych. Wrażliwość na własną godność ma różne odcienie w odmiennych kulturach. Poczucie godności i postawa godnościowa w określonym społeczeństwie kształtuje się w ramach wychowania społeczno-moralnego, poprzez zaprogramowaną (intencjonalną) i spontaniczną działalność człowieka, dzięki oddziaływaniu różnych grup społecznych, ideologii społeczno-politycznych, środków społecznego przekazu, szkoły, religii i Kościołów itp. Odkrycie i rozwijanie własnej godności dokonuje się w społeczeństwie, w kontaktach i interakcjach społecznych, poprzez aktywność twórczą i innowacyjną, w działaniach prospołecznych, a zwłaszcza altruistycznych, w rozwiązywaniu konfliktów i napięć, w aktach odpowiedzialności i winy moralnej związanych z naruszaniem własnej lub cudzej godności.

Źródłem godności osobistej jest aktywność osoby ludzkiej, będąca wyrazem: po pierwsze, obrony własnej tożsamości i własnych przekonań; po drugie, podmiotowego traktowania drugiego człowieka i pozytywnych więzi emocjonalnych z tym człowiekiem, niesienia mu pomocy w potrzebie; po trzecie, w twórczości, której efektem są wzbogacające kulturę, nowe idee i przedmioty. Godność ta jako przymiot nabyty w trakcie życia nie ma charakteru stałego, podlega różnym fluktuacjom, może nawet ulec zniweczeniu pod wpływem presji zewnętrznych. Nie jest wartością wrodzoną, lecz cechą nabytą, ukształtowaną pod wpływem aktywności własnej i życiowych doświadczeń. Trzeba ją pielęgnować, dbać i zabiegać o nią przez przyzwoite życie (por. Mikrut, 2016, s. 109).

W godności osobistej nie można eksponować tylko postępowań człowieka zgodnych z jego własnym systemem wartości i przekonań, pozostawaniem wiernym sobie, czy będących wyrazem obrony swojej tożsamości i indywidualności. Takimi cechami mogą się odznaczać ludzie postępujący niemoralnie, np. wyrafinowani przestępcy. Nie chodzi też tylko o zewnętrzne formy zachowań, ale przede wszystkim o zachowania moralne, czyli godne człowieka. Człowiek z etycznym poczuciem godności własnej ma świadomość, że „wykuwa siebie w sobie samym” jako wartościowe dzieło, którego dokonuje jako istota moralna w sobie (Gajda, 2013, s. 135).

Poczucie godności jest zjawiskiem przede wszystkim natury psychologicznej. Może ulec destrukcji bądź na skutek działania innych osób lub w wyniku własnego niemoralnego 


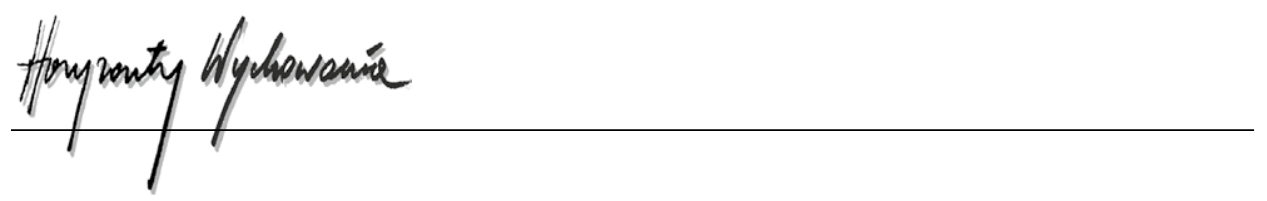

zachowania (por. Mikrut, 2014, s. 19-32). Każdej osobie ludzkiej - niezależnie od warunków, w jakich przychodzi jej egzystować - przysługuje wyjątkowa godność i szczególna wartość. Człowiek nie jest „wartością użytkową” czy „wartością pragmatyczną”. Imperatyw moralny nakazuje uznanie i chronienie każdej osoby, także niepełnosprawnej, w takim samym stopniu i w takim samym zakresie, jak czyni się to w stosunku do godności wszystkich innych ludzi (Mikrut, 2013, s. 387).

Poczucie godności jest więc stanem świadomościowym konkretnej jednostki i konsekwencją jej indywidualnych doświadczeń życiowych. To dzięki uporczywej, długofalowej pracy ukierunkowanej na realizację powszechnie uznawanych wartości, jakimi są dobro, prawda i piękno, jednostka ujawnia, ale i doskonali swoją dojrzałość moralną. Dzięki temu typu działalności kształtuje u siebie takie cechy i przymioty, jak: honor, dobre imię, szacunek do siebie czy wspomniane już poczucie własnej wartości, które - zdaniem Marii Ossowskiej świadczą o tzw. godności osobowościowej (Mikrut, 2013, s. 386).

Z socjologicznego punktu widzenia w postawie godnościowej ważną rolę odgrywa szacunek dla własnych przekonań i umiejętność ich obrony, związana z postawą wierności sobie oraz poszukiwaniem zgodności między wewnętrznymi przekonaniami a publicznym postępowaniem. Ludzie o postawie godnościowej są przekonani, iż powinni postępować zgodnie z własnymi przekonaniami, że powinni sprzeciwiać się wszelkim próbom indoktrynacji i manipulacji. Charakteryzują się oni zdolnością do moralnej transcendencji, której celem jest nie tyle dostosowanie się do istniejącego porządku społecznego, ile raczej tworzenie wartości, troska o ich zachowanie i gotowość poniesienia konsekwencji dokonanego wyboru. Aby być wiernym swoim poglądom, uznawanym wartościom czy zamierzonym celom, a także szanować przekonania innych, trzeba zrozumieć do głębi, kim się jest, zrozumieć ideę człowieczeństwa.

\section{Godność osobista jako wartość pozytywna}

Godność ludzka z psychologicznego punktu widzenia jest wartością zmienną, oscyluje między biegunami optymizmu i abnegacji. Człowiek z poczuciem godności potrafi umiejętnie przeżyć różnego rodzaju trudne sytuacje, cierpienia, niepowodzenia, akceptując z godnością przeciwności życia. Niekiedy dochodzi do deformacji poczucia własnej wartości (zaniżanie lub zbytnie jej zawyżanie), co prowadzi do różnych form dezintegracji osobowości (por. Stępień, 2016, s. 380). Godność ludzka wiąże się z odczuwaniem i oceną swojego postępowania i innych osób jako odpowiadającego kryteriom o charakterze słusznościowym.

Godny jest ten, kto nie rezygnuje z działania w swoim przekonaniu słusznego, nie narusza własnej i cudzej godności przez czyny godne pogardy, jest zdecydowany bronić swojej i cudzej godności w sposób zdecydowany, nawet za cenę bardzo wysoką. O godności osobistej decyduje więc „posiadanie hierarchii wartości, do której jest się przywiązanym i z której nie zamierza się zrezygnować. Uparta obrona tych wartości stanowi 
o postawie, którą nazywamy godnością" (Ossowska, 1983, s. 559). Ludzie nie zawsze jednak odwołują się do godności jako podstawy pochwały lub nagany pewnych zachowań własnych lub cudzych.

Godność osobista - tak jak jest ona rozumiana na gruncie psychologii i socjologii - wiąże się z gotowością obrony uznawanych wartości, a nawet poświęcenia dla nich innych ważnych dóbr, z własnym życiem włącznie. Jest więc ona „relatywizowana” przez odniesienie jej do uznawanych i realizowanych wartości. Jako naturalny składnik osobowości godność jest trwałym przekonaniem jednostki o jej autentycznej wartości jako człowieka będącego całością niepodzielną. Wierność sobie i pragnienie życia z godnością sprawia, że „człowiek z ukształtowanym poczuciem godności umie lepiej czy gorzej - bronić swojego «ja», pozostaje wierny sobie w najtrudniejszych okolicznościach" (Kozielecki, 1977, s. 10, 25). Wynika stąd, że godność - z psychospołecznego punktu widzenia - nie jest wartością „równowartościową” u wszystkich.

Godność osobista rozumiana jako poczucie godności własnej jest bardzo skomplikowanym konstruktem, który może być rozpatrywany z różnych perspektyw badawczych. Badania socjologiczne, których wyniki tu referujemy, ujawniły bogaty treściowo obraz poczucia godnościowego respondentów, powiązanego z ich zainteresowaniami, emocjami, poglądami, ocenami i doświadczeniami. Można wyróżnić trzy podstawowe kategorie ocen wysokiego poczucia godności ludzkiej: pozytywne, pozytywno-negatywne, negatywne oraz dodatkowo wypowiedzi ogólnikowe lub wyrażające brak stanowiska w tej sprawie.

Oto wybrane przykładowo oceny pozytywne wypowiadane pod adresem osób o wysokim poczuciu godności osobistej: Są to osoby, które egzekwują swoje prawa i zazwyczaj walczą o prawa osób, które pozbawione są godności w różny sposób (praca niewolnicza, ludzie żyjący w krajach objętych wojną lub dyktaturą itd.). Często takie osoby są aktywistami społecznymi i niosą pomoc słabszym (A); Według mnie są to ludzie bardzo silni, pewni siebie. Osoby te doskonale znają swoje życie, w pełni je akceptując. Są to ludzie bardzo świadomi swojej wartości i praw. Mam wrażenie, że te osoby respektują prawa człowieka drugiej osoby (A); Według mnie ludzie o wysokiej wartości własnej posiadają mocny kręgosłup moralny. Tacy ludzie żyją zgodnie z przyjętymi ogólnie wartościami, nie łamią systemów niezależnych, cenią siebie, a także innych (S); Ludzie mający szacunek do siebie zazwyczaj potrafią również kochać bliźnich (P); Oceniam tych ludzi bardzo pozytywnie, ponieważ są to osoby, które szanują, kochają samego siebie. Mają świadomość, że zasługują na szacunek, wiedzą, czego chcą, że są zdolni do wielkich rzeczy (P); Moim zdaniem posiadanie wysokiego poczucia godności własnej jest zaletą. Każdy człowiek bez względu na stan zdrowia, sytuację materialną czy inne czynniki posiada godność ludzką. Jednak ludzie o wysokim poczuciu godności są bardziej świadomi, że stworzeni są na podobieństwo Boga, że są wyjątkowi, dlatego starają się w jak najlepszy sposób dawać świadectwo swojego człowieczeństwa (A); Ludzie, którzy mają wysokie poczucie własnej godności, zasługują na podziw i chęć naśladowania, są dobrym wzorem, jak poradzić sobie w życiu, i nigdy nie upaść na dno oraz nie dać zrobić z siebie niewolnika $(\mathrm{P})$; Uważam, że są to ludzie, którzy mają w sobie 


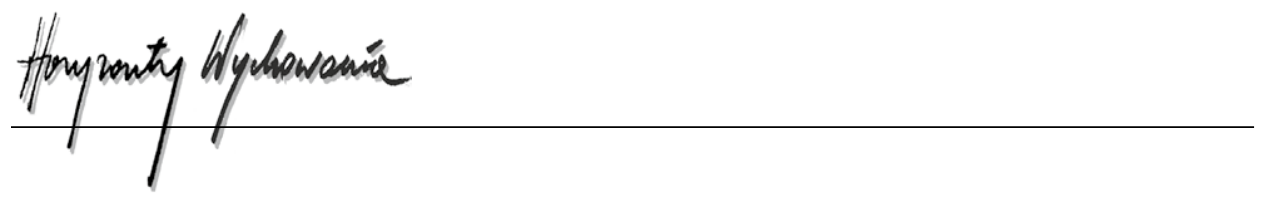

więcej empatii (A); Według mnie osoby, które mają poczucie wysokiej godności własnej, są osobami odważnymi, niebojącymi się podejmować ryzykownych działań, asertywni, akceptujący siebie, niebojący się krytyki, otwarci na zmiany (A); Uważam, iż każdy człowiek powinien posiadać wysokie poczucie własnej godności, dzięki temu ludzie potrafią myśleć i radzić sobie z podstawowymi życiowymi wyzwaniami, wierzyć w swoje możliwości i wysoką samooceną. Wysokie poczucie godności daje człowiekowi przekonanie, że każdy ma prawo do szczęścia i do tego, że jesteśmy ważni i zasługujemy na zaspokojenie swoich pragnień. Człowiek mający wysokie poczucie godności jest zadowolony z owoców swej pracy, ma szacunek dla siebie, uznaje prawa do szacunku innych (A); Ludzie o wysokim poczuciu godności są osobami, które mają w swoim życiu niepisane reguły i ich przestrzegają. Potrafią dochować tajemnicy, są lojalni (O); Uważam, że tacy ludzie są przykładnymi obywatelami (A); Szanują ludzi bez względu na ich pochodzenie, kolor skóry czy też wykształcenie. Nie ma dla mnie znaczenia czy ktoś jest osoba pracującą fizycznie (np. pani sprzątaczka), czy też jest prezesem dużej firmy korporacyjnej (O); Ludzie o wysokim poczuciu własnej godności są raczej tolerancyjni, często mają dystans do siebie, dobrze się czują w ,,swojej skórze”, są pozytywnie nastawieni. Dobrze znają swoje zdanie, poglądy i nie wstydzą się i łatwo ich nie zmieniają (O); To ludzie, których ciężko jest złamać, upokorzyć. Dobrze znający swoją wartość, o wysokim poczuciu własnej tożsamości i swojego miejsca w świecie (O); Pozytywnie, ponieważ doceniają dar, który otrzymali od Boga. Są zmotywowani do życia, przejawiają szacunek i respektowanie do innych ludzi (P); Cenię sobie ludzi o wysokiej godności, powinny być one dla nas wzorem do naśladowania (S); Ludzie o wysokim poczuciu własnej godności są świadomi, są świadomi swojej osoby, czują się dobrze sami ze sobą (S); Oceniam ich bardzo dobrze, wiem, że oni podejmują świadome decyzje, zgodne z ich wartościami. Tacy ludzie wiodą szczęśliwe życie, bo rozumieją siebie i innych (S) ${ }^{1}$.

Jeżeli godność osobistą będziemy wiązać - zgodnie z postulatami Marii Ossowskiej i Józefa Kozieleckiego - z posiadaniem wartości i ich obroną, to wypowiedzi młodzieży wykraczają daleko poza takie określenia. Według respondentów ludzie o wysokim poczuciu godności osobistej: są dochowujący tajemnicy i lojalności; są tolerancyjni; nie dają się złamać; żyją zgodnie z wartościami i zasadami, nie ulegają naciskom zewnętrznym; potrafią bronić swojej godności; są wzorami do naśladowania; są szanowani w społeczeństwie; odnoszą się do innych z szacunkiem; są godni zaufania; są pewni siebie, stawiają sobie wyraźne cele w życiu; potrafią pomagać innym ludziom, także bezinteresownie; wiedzą, co w życiu jest ważne; potrafią kochać bliźnich; dążą do wysoko postawionych celów; akceptują siebie i innych; są odpowiedzialni i wrażliwi na los i cierpienie innych ludzi; są empatyczni; są otwarci na świat, podejmują próby jego naprawy; swoją godność

\footnotetext{
${ }^{1}$ Wypowiedzi respondentów są opatrzone następującymi znakami: „A” - studenci Wyższej Szkoły Nauk Społecznych z siedzibą w Lublinie; „P” - studenci pedagogiki Katolickiego Uniwersytetu Lubelskiego Jana Pawła II; „O” - studenci Uniwersytetu Warmińsko-Mazurskiego w Olsztynie; „S” - młodzież szkół średnich w Stalowej Woli.
} 
traktują jako dar Boży; kochają siebie i bliźniego; są asertywni; potrafią dokonywać właściwych wyborów; są sprawiedliwi i uczciwi (por. Ostrowska, 2004, s. 248-249).

Idąc tropem proponowanych badań empirycznych, można rozwinąć i uzupełnić tezy tych, którzy zawężają kwestię godności do umiejętności obrony pewnych uznawanych przez siebie wartości. Przede wszystkim badani uszczegóławiają wartości charakteryzujące człowieka o wysokim poczuciu godności, to m.in. uczciwość, sprawiedliwość, empatia, odpowiedzialność, asertywność, dążenie do wybranych celów. Ludzie ci dokonują kompetentnych i twórczych wyborów z nieprzeniknionego bogactwa wartości, podejmują próby doskonalenia siebie i okazują szacunek dla innych. Hasło „szanuj godność własną i cudzą" wybrzmiewa - bezpośrednio lub pośrednio - u większości tych, którzy dostrzegają pozytywne cechy u ludzi z wysoką godnością własną. Nie powinno to dziwić, skoro według sondażu CBOS ze stycznia 2014 r. - 42\% badanych dorosłych Polaków zaliczyło wartość „szacunek innych ludzi” do najważniejszych wartości w swoim codziennym życiu (piąta pozycja wśród szesnastu ocenianych wartości) (por. Boguszewski, 2019, s. 2).

Godności osobistej nadaje się więc wymiar moralny. Ludzie o takich nastawieniach i takich orientacjach życiowych nie wykazują wyraźnej skłonności do wywyższania się, troski o dobro własne czy koncentracji na własnym ,ja”. Wręcz przeciwnie, są skłonni działać - w większości przypadków - dla dobra innych ludzi. Są otwarci na innych, tolerancyjni i empatyczni. Te pozytywne oceny odnoszą się - w zróżnicowany sposób - do poszczególnych osób o wysokim poczuciu godnościowym.

\section{Godność osobista jako wartość ambiwalentna}

Socjologowie moralności nie operują egalitarnym pojęciem godności ludzkiej, czyli właściwości przypisywanej każdemu człowiekowi. Zwracają uwagę na to, że godność jest w pewnym sensie funkcją kształtowania się świadomości i zawiera w sobie element potencjalności. Każdy może być świadomy w większym lub mniejszym stopniu swojej godności. Może ją odpowiednio rozwijać, udoskonalać i dopełniać. Poczucie godności jest stopniowalne.

Skłonność do przypisywania sobie wartości i żądania od innych jej akceptacji jest tym, co w języku potocznym nazywamy „poczuciem własnej godności” lub „ambicją”. Tendencja owa wypływa z części duszy określanej jako thymos i jest jak gdyby wrodzonym zmysłem sprawiedliwości. Istoty ludzkie wierzą, iż posiadają wewnętrzną wartość, a kiedy ktoś odmawia im tego lub ich wartość niżej wycenia, wtedy doświadczają uczucia gniewu. $Z$ kolei życie niezgodne z poczuciem własnej wartości wywołuje wstyd, natomiast właściwa jej ocena - dumę (Fukuyama, 1996, s. 16).

Szacunek dla samego siebie jest niezbędnym warunkiem integracji osobowościowej, utrata zaś szacunku jawi się jako symptom dezintegracji. W interpretacji psychospołecznej godność nie przysługuje automatycznie każdemu człowiekowi, są bowiem ludzie, którzy ją posiadają, i są tacy, którzy ją tracą lub ją utracili. Zależy ona od świadomości 


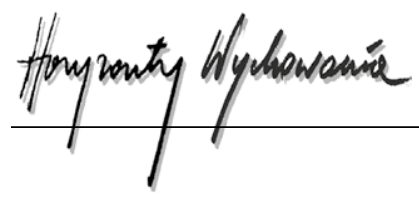

jednostki i cech indywidualnego sposobu postępowania. Zwłaszcza w sytuacjach osobistego zagrożenia człowiek może utracić swoją godność, utrzymać ją lub ją odzyskać. Jednostka może się godzić na poniżenie własnej tożsamości osobowej lub się nie godzić, może poniżać godność innych lub ją szanować, nie czynić nic, co uwłaczałoby godności innych. W języku potocznym określa się działania zabezpieczające poczucie godności terminem „zachować twarz”. W ręku człowieka leży moc nadawania sobie lub odbierania „ludzkiej twarzy”.

Przytoczymy teraz wypowiedzi tych respondentów, którzy dostrzegają pozytywne i zarazem negatywne cechy u osób charakteryzujących się wysokim poczuciem godności własnej: Jeżeli wysokie poczucie godności własnej zawiera również aspekt krytyczny, jak i nie jest ono bardzo mocno ukazywane w relacjach z innymi, to sądzę, że jest dobre i właściwe (P); Uważam, że każdy człowiek powinien mieć równy poziom swojej godności, przez co jednostki, które mają niższe poczucie własnej godności, winny być niejako dowartościowywane, zaś ci, którzy mają tę godność nazbyt wysoką, powinni zrozumieć to, by nie wywyższać się ponad szereg, gdyż jak wspomniałem wcześniej, każdy urodził się równy i dokładnie w taki sam sposób powinien być traktowany (A); Szanuję ludzi o wysokim poczuciu godności, chyba że reprezentuje się w ten sposób osoba, która nie przestrzega zasad moralnych (A); Myślę, że ludzie, którzy mają wysokie poczucie własnej wartości, różnicują się na tych, którzy mają je i się z tym nie obnoszą, jest to coś dla nich samych, nie są egoistami. Oraz ludzie, którzy mają poczucie, że są lepsi od innych, mają bardzo wysokie mniemanie na swój temat oraz afiszują się z tym, co czasem jest błędne. Myślę, że nie jest to potrzebne, wystarczy mieć świadomość swojej wartości i zatrzymać to dla siebie, każdy to doceni (P); Raczej są to osoby wykształcone, inteligentne, ale pyszałkowate (S); To ludzie, którzy są pewni siebie, znają swoją wartość, nie cenią innych (A); Zazwyczaj szanuję takich ludzi, chyba że wynika ona z błędnego postrzegania własnej osoby (A); Uważam, że każdy powinien mieć swoją własną godność. Jednak osoby o zbyt wysokiej godności często mają o sobie zbyt wysokie mniemanie. Ciężko wtedy przyjmują krytykę i inne zdanie, szybko się oburzają i są dość wyniosłe (O); To zależy od wieku. Im człowiek starszy, tym poczucie godności powinno być wyższe. Składają się na to doświadczenia. Wysokie poczucie godności pozwala lepiej żyć (O); Oceniam ich pozytywnie, o ile nie jest to skrajność, zamieniająca się w pychę czy arogancję. Każdy powinien być szanowany i mieć szacunek do innych. Jest to istotna wartość w życiu społecznym, ponadto zwiększa to pewność siebie, co jest korzystne dla tych osób (O); Zależy od sytuacji. Jeżeli mają podobne wartości do moich, to pozytywnie (O); Moim zdaniem są oni godni zaufania, można się na nich opierać, pokazują tym, że osiągnęli ogromny sukces kosztem dużego wkładu pracy. Jednak jak wszystko i to ma swoje minusy (S); Często można pomylić osoby o wysokim poczuciu godności z osobami mającymi wysokie mniemanie o sobie i zadzierającymi zwyczajowego nosa. Jeżeli taka osoba w swoim życiu niczym nie uchybiała, to oczywiście oceniam ją dobrze i darzę ją szacunkiem (P); Dopóki jest ono na zdrowym poziomie, a osoba taka nie uważa się za lepszą od reszty, to uważam, że jest to dobra rzecz. Jeśli taka osoba wywyższa się i obraża o najdrobniejsze rzeczy, ponieważ czuje, że godzą one w jego godność, to jest 
zwyczajnie przewrażliwiona i nie potrafi podejść do siebie z dystansem (P); Myślę, że są to osoby, z którymi warto przebywać, zwykle są świadome siebie i otoczenia, w miarę pewne siebie, choć czasem mogą nadinterpretować swoją godność i być nieprzyjemnymi osobami. Mimo wszystko osoby o wysokim poczuciu własnej godności wydają mi się dużo szczęśliwsze (O); Warto mieć świadomość i poczucie własnej godności, czuję respekt do ludzi, którzy takowe posiadają, ale uważam, że jest cienka granica między wywyższaniem się (na co ja źle patrzę) a wysokim poczuciem godności (S).

Ambiwalentne oceny można ująć krótko w następujący sposób: a) szanują godność ludzi lub nie szanują; b) mocno ukazywana cecha lub słabo akcentowana; c) nie wywyższają się nad innych lub wywyższają; d) przestrzegają zasad moralnych lub nie przestrzegają; e) pozytywnie nastawieni wobec innych lub negatywnie; f) świadomi swojej wartości lub wynoszący się ponad innych; g) dążący do wybranych celów lub lekceważący innych; h) inteligentni, ale pyszałkowaci; i) szczęśliwsi od innych, ale są osobami nieprzyjemnymi; j) do pewnego stopnia jest to cecha pozytywna; k) poczucie godności może być zawyżone albo zaniżone; l) poczucie ważności siebie, ale w rozsądny sposób.

W ocenach i doświadczeniach badanej młodzieży ludzie o wysokim poczuciu godności własnej są mocno zróżnicowani. Ich postawy można określać w formie wyżej przytoczonych alternatyw. Niektóre pozytywne oceny są zaopatrzone różnego rodzaju zastrzeżeniami lub wątpliwościami. Inni są skłonni uważać, że tacy ludzie pojawiają się rzadko, czasem zmieniają swoje postawy lub są niekonsekwentni w swoich działaniach. Deklarowane oceny są więc nie zawsze pozytywne i nie zawsze negatywne, są ambiwalentne. Wiele zależy od tego, jak są one ukształtowane i realizowane w konkretnych sytuacjach życiowych.

\section{Godność osobista jako antywartość}

Godność osobista - psychologicznie rzecz biorąc - jest rzeczywistością zmienną, może wyrażać się zarówno poczuciem niższości, jak i postawą nadmiernej roszczeniowości. Poczucie godności ludzkiej nie jest wolne od różnego rodzaju pułapek interpretacyjnych i nachylenia roszczeniowego. Nadmierne podkreślanie przez jednostkę jej własnej godności może prowadzić do jakiejś deformacji egoistycznej.

Godność osobista można więc pomniejszyć lub utracić przez swą orientację aksjologiczną „w dół”, przez rozdźwięk między preferowanymi a urzeczywistnianymi wartościami. Można je również budować poprzez wierność swej osobowej wartości, dokonywanie wyborów moralnych, służbę drugiemu człowiekowi w myśl normy personalistycznej (Chałas, 2006, s. 124).

Godność osobowościowa i osobista nie jest wartością statyczną, lecz dynamiczną, rozwija się w przestrzeni międzyosobowej, we wspólnocie osób, dialogowo jako relacja zachodząca między „ja” i „ty”.

Współcześnie wielu ludzi odwołuje się do godności, słyszy się o niej w bardzo różnych kontekstach i sytuacjach. Godność daje się łatwo użyć do dowolnej niemal propagandy 


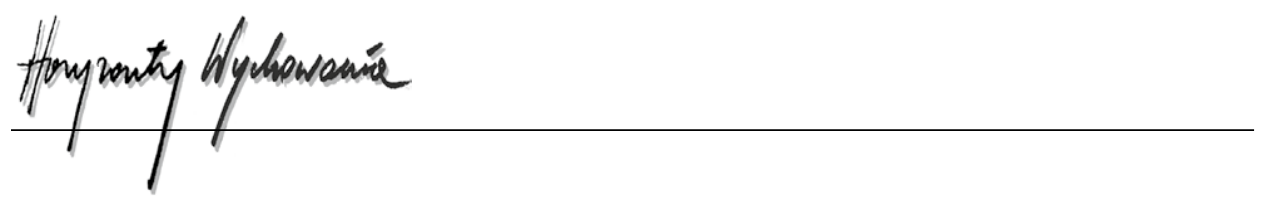

i dowolnego kaznodziejstwa. Na różne niebezpieczeństwa związane z retoryką godności wskazuje Andrzej Grzegorczyk. Oto niektóre ze skutków operowania niewłaściwym pojęciem godności, prowadzące na swoiste manowce.

1. Inspiracja wywodząca się z godności i wzywająca do konsekwencji może grozić sztywnością postępowania, uporem i trudnością przyznania się do winy lub błędu. Jeżeli jednostka przyzna się do braku konsekwencji, do zaniedbywania reguł obowiązujących w jej grupie społecznej, to przestaje być w mitycznym sensie członkiem grupy, symbolicznie skazuje siebie na banicję. Aby nie stracić swojej godności członka grupy, w różny sposób popada w zakłamanie.

2. Hasło obrony własnej godności może prowadzić do kontestacji dowolnego przymusu i posłuszeństwa. Skoro jestem rozumny i mam bronić swojej rozumności i samostanowienia, to nie powinienem nikogo słuchać. Nikt nie powinien mi rozkazywać, tylko powinien mnie przekonywać. Jeżeli przekona mnie, to sam zadecyduję, jeśli nie przekona, to nie mogę działać wbrew własnym argumentom. Nie należy słuchać żadnych rozkazów czy rozporządzeń, należy je traktować jako uwłaczającą procedurę skierowaną na pomniejszenie naszej osobowości.

3. Rozważając swój sukces czy szczęśliwy traf, mogę wbijać siebie w zarozumialstwo, poczucie triumfu, w pewność siebie, w przekonanie o swojej wyższości nad innymi, czyli w ten kompleks emocji, który tradycyjnie był nazywany pychą. Rozważając z kolei swoje klęski, winę, nieudolność, niepowodzenia i upadki, jednostka może przeżywać swoją małość, nieważność, czyli pokorę wobec losu, rzeczywistości czy innych ludzi. Do pewnego stopnia każdy człowiek balansuje na tej linii, między poczuciem własnej wartości i wielkości a poczuciem małości i nieważności. Pycha stanowi wyraźnie negatywny kraniec poczucia własnej wartości.

4. Postawy roszczeniowe prowadzą łatwo do życia w atmosferze pretensji do innych, do stawiania siebie w pozycji nadrzędnej, uzurpowania sobie atrybutów ,,boskości”. Zamiast odkrywać sens w obiektywnej wizji świata, staramy się narzucać rzeczywistości sens przez nas zadekretowany. Emocjonalne przywiązanie do własnych wyobrażeń ogranicza nasz krytycyzm i obiektywizm w ocenie rzeczywistości. Stawiamy wtedy zazwyczaj większe wymagania innym niż sobie. Zafałszowane poczucie swojej wartości usprawiedliwia dążenie do uprzywilejowanej pozycji, często wręcz zezwala na dominację. Ideologia godności staje się częścią składową ideologii własnej dominacji nad innymi, a nawet może się degenerować w postawę przemocy (por. Grzegorczyk, 1983, s. 67-72).

Negatywne określenia ludzi o wysokim poczuciu godności osobistej pojawiają się stosunkowo rzadko. Oto wybrane wypowiedzi: Oceniając postawy społeczne, np. świat polityki, uważam, że mało jest godnych zachowań osób publicznych, które są osobami medialnymi i poniekąd wzorcami społecznymi. Jeżeli przykład idzie z góry, to poniekąd usprawiedliwia samego obywatela, że coś załatwi w sposób ,,nieczysty” (A); Osoby, które uważają, że mają wysokie poczucie godności, w mojej opinii zazwyczaj są to osoby, które mają przekonanie, że tylko one umieją wszystko najlepiej i dla nich nie liczy się zdanie innych, wręcz nie biorą pod uwagę czyjejś opinii, uważają ją za błędną, niepotrzebną. 
Dlatego oceniam takich ludzi negatywnie, ponieważ takie osoby nie są dla mnie dobrymi osobami, aby z nimi utrzymywać kontakt (P); Dobrze jest, jeśli człowiek ma wysokie poczucie swojej godności, ponieważ często może go to ustrzec przed podjęciem zgubnych w skutkach decyzji, dyktowanych chwilą lub wpływem innych. Natomiast źle jest, jeśli poczucie godności zamienia się w zarozumialstwo i wywyższanie się nad słabszymi od nas (A); Nie oceniam tych ludzi, jednak uważam, iż jak sama godność ma dolną granicę, posiada ona również górną, której także nie powinno się przekraczać. Zbyt wysokie poczucie własnej wartości może negatywnie wpłynąć na niektóre cechy danej osoby (A); Ludzi o wysokim poczuciu godności własnej oceniam raczej źle, ponieważ czasami, kiedy ktoś potrzebuje pomocy, mówią, że oni nie mogą pomóc, bo mogą to inni zrobić, myślą o sobie samych (P); Myślę, że ludzie o wysokim poczuciu godności własnej są bardzo pewni siebie, czasami nawet aż za bardzo, są odważni, niekiedy nawet uważają się za lepszych od innych ludzi, są asertywni, dbają i walczą o swoje dobro, jednocześnie można na nich polegać, są godni zaufania (O); Czasami mają za wysokie poczucie własnej godności i nawet w kryzysowej sytuacji nie chcą prosić o pomoc, ponieważ według nich nie byłoby to godne, a przecież nikt nie jest samowystarczalny w pełni i każdy potrzebuje pomocy. Nie jesteśmy w stanie poradzić sobie sami z każdym napotkanym problemem (O); Czasem tacy ludzie są zapatrzeni tylko i wyłącznie na siebie, zapominają o dobru innych. Często tacy ludzie przeceniają swoją wartość (O); Nie można mieć za wysokie poczucie własnej godności, ponieważ wtedy stajemy się ślepi na innych, nie przyjmujemy ich ją do siebie (A); Zbyt duża godność jest dla mnie złą rzeczą. Uważać siebie lepszym od wszystkich, to już przechwalanie się, każdy powinien wiedzieć, kim jest i na co zasługuje. Zbyt wiele w życiu krytykować, to nie jest dobre (A); Są to ludzie uparci, nie są skorzy do uznania własnej porażki. Trudno im przyznać się do błędu. Są to ludzie honorowi. W większości ludzie o wysokim poczuciu godności to patrioci (S); W sąsiedniej rodzinie dochodzi często do naruszania godności, ponieważ mąż nie szanuje żony. Uważa, że jest nikim, że nic nie osiągnie w życiu, zdarzały się również pobicia $(\mathrm{P})$.

Są wreszcie i tacy wśród badanej młodzieży, którzy nie udzielili odpowiedzi, lub przyznawali się do niewiedzy: Nie do końca wiem, jak wyrazić moją opinię na ten temat (O); To fikcja (S); Nigdy się nie zastanawiałem, jak można ją opisać (A).

\section{Uwagi końcowe}

Godność ludzka rozumiana jako poczucie godności, przekonanie o swojej godności, ma przede wszystkim wymiar subiektywny, związany z odczuciem własnej wartości czy poczuciem honoru. Uzależniona jest ona od obrazu samego siebie i od stopnia osobistej wrażliwości. Godność osobista jest czymś prywatnym i nie może być zawsze postrzegana przez osoby postronne. Wysoka godność osobista może współwystępować z zaniżoną godnością osobowościową (Hołub, 2014, s. 93). Godność osobista utożsamia się z posiadaniem poczucia własnej wartości. Człowiek nie tylko posiada godność, ale 


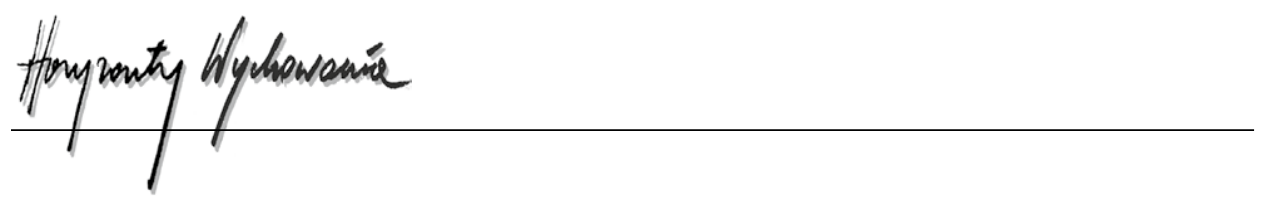

też może być jej świadomy w większym lub mniejszym stopniu oraz rozmaicie ją przeżywać. U podstaw poczucia własnej godności (postawa człowieka, cecha indywidualna) leży świadomość, wolność i odpowiedzialność, które to cechy domagają się utrwalenia i rozwoju. Świadomość własnej godności integruje osobowość człowieka i ją wzmacnia, dodatnio wpływa na życie. Przejawia się m.in. w pozytywnej postawie wobec samego siebie i innych ludzi, w przekonaniu, że żyje się właściwie i broni się własnej tożsamości i indywidualności (Dłubacz, 2014, s. 26-27). Poczucie własnej godności może być szczególnie intensywnie przeżywane w warunkach ekstremalnych, w sytuacjach instrumentalnego czy przedmiotowego traktowania przez innych ludzi.

Po przeprowadzeniu w miarę dokładnych analiz ustaliłem następującą częstotliwość deklarowanych ocen na temat osób o wysokim poczuciu godności: określenia pozytywne - 51,0\%; wypowiedzi ambiwalentne (pozytywne i negatywne zarazem) - 21,2\%; określenia negatywne - 10,9\%; niezdecydowani, niemający zdania, przyznający się do niewiedzy lub w ogóle nieudzielający odpowiedzi - 9,7\%; wypowiedzi ogólnikowe - 7,2\%. Łącząc odpowiedzi pierwszą i czwartą, otrzymujemy wskaźnik około $60 \%$ tych, którzy deklarują pozytywne - niekiedy ogólnikowe - oceny o ludziach charakteryzujących się wysokim poczuciem godności własnej (por. Kanclerz, 2015, s. 161-162). Tylko co dziesiąty badany wyrażał negatywne oceny o takich osobach. Niektórzy ankietowani mieli trudności z podaniem bliższych określeń, czym jest godność osobista, lub uważali to pojęcie za niedefiniowalne (por. Pasteczko 2012, s. 161-172).

Młodzież pozytywnie oceniająca osoby o wysokim poczuciu godności własnej dość często podkreślała, że osoby o takich właściwościach cechują się docenianiem godności własnej i godności innych ludzi („szanuj godność własną i cudzą”). Przeważała interpretacja prospołeczna godności ludzkiej nad interpretacją indywidualistyczną. Takie nastawienie służy harmonizowaniu dobra indywidualnego z dobrem wspólnym, obowiązków moralnych wobec siebie i wobec innych. Osoby o wysokim poczuciu godnościowym są odbierane przez większość pozytywnie je oceniających jako respektujące reguły i zasady określające, co jest dobre, a co złe, co należy czynić, a czego unikać (moralny wymiar godności ludzkiej). Godność osobista wiąże się tu z odczuwaniem i oceną swojego postępowania jako odpowiadającego kryteriom o charakterze słusznościowym. Jeżeli człowiek zaakceptuje coś, co być nie powinno, traci swoją godność wewnętrzną. Tylko nieliczni respondenci usiłowali łączyć godność ludzką z wymiarami religijnymi.

W kontekście przeprowadzonych badań socjologicznych wskazujących na jeszcze znaczącą obecność wartości godnościowych w świadomości młodzieży polskiej można by wyrazić postulat, by nauki społeczne podejmowały w większym zakresie problematykę godności ludzkiej, by stała się ona swoistą modą w psychologii, socjologii i pedagogice, co byłoby także wkładem w przezwyciężanie kryzysu moralnego we współczesnym świecie. Drugie życzenie odnosi się do Kościoła katolickiego (i innych Kościołów chrześcijańskich oraz religii) w naszym kraju, by ustawicznie głosił prawdę o godności każdego człowieka i krytycznie osądzał - z etycznego punktu widzenia - sytuacje uwłaczające godności ludzkiej. Tych ostatnich w społeczeństwie polskim nie brakuje i nie zabraknie w przyszłości. Społeczeństwo godnościowe potrzebuje godnie postępujących 
ludzi, dobre społeczeństwo nie będzie istnieć bez dobrych ludzi. Mówienie o godności człowieka w kontekście społecznych związków i uwarunkowań (godność społeczna) i osobistych przekonań (godność osobista) byłoby czymś niepełnym bez odniesienia do ontycznej godności osoby ludzkiej, „wpisanej” w człowieczeństwo każdego z nas.

W sytuacji, gdy wielu ludzi traci właściwe poczucie godności osobistej i osobowościowej, postulat budzenia poczucia godności i jej poszanowania staje się wyzwaniem i zadaniem edukacyjnym dla wszystkich podmiotów interakcji w procesach wychowawczych i dydaktycznych. „Poszanowanie godności stanowi podstawowy warunek rozwiazywania problemów wychowawczych, dialogu, owocnego współdziałania, poszerzania przestrzeni, w której urzeczywistnianie wartości znajdzie swe znaczące miejsce" (Chałas, 2006, s. 126). Te zadania wychowawcze Krystyna Chałas przedstawia w następujący sposób:

Uczyć stylu życia charakterystycznego dla człowieka aktywnego, który potrafi odpowiedzialnie i sprawnie osiągnąć zamierzone cele, rozwiązywać problemy moralne, twórczo pracować i urzeczywistniać wartości moralne, szanować siebie i drugiego człowieka. Zrozumienie istoty godności staje się podstawą do jej szanowania, które wyraża się w afirmowaniu wartości osoby, postawienia jej w centrum swoich celów, decyzji, sposobów działania (Chałas, 2006, s. 135).

W wychowaniu moralnym godność ludzka jest wartością priorytetową (por. Rynio 2019, s. 161-177).

\section{BIBLIOGRAFIA}

Archer, M.S. (2017). Morfogeneza tożsamości osobistej. Jesteśmy tym, na czym nam zależy. Tł. P. Wielecki. W: Prof. dr hab. Margaret S. Archer doktor honoris causa Uniwersytetu Kardynała Stefana Wyszyńskiego w Warszawie. Warszawa: Wydawnictwo Naukowe UKSW.

Boguszewski, R. (2019). Rodzina - jej znaczenie i rozumienie. Komunikat z badań CBOS, nr 22.

Chałas, K. (2006). Wychowanie ku wartościom. Elementy teorii i praktyki. T. I (Godność, wolność, odpowiedzialność, tolerancja). Lublin - Kielce: Wydawnictwo Jedność.

Chlewiński, Z. i Zaleski Z. (1989). Godność. W: L. Bieńkowski i in. (red.), Encyklopedia katolicka. T. V, kol. 1231-1232. Lublin: Towarzystwo Naukowe KUL.

Dłubacz, W. (2014). O pojęciu godności i antropologicznym wymiarze pracy. W: W. Dłubacz (red.), Godność - Praca - Globalizacja. Stalowa Wola: Wydawnictwo Sztafeta.

Fukuyama, F. (1996). Koniec historii. Tł. T. Biedroń, M. Wichrowski. Poznań: Wydawnictwo Zysk i S-ka.

Furmanek, W. (2013). Godność obiektem badań nauk humanistycznych. W: W. Furmanek (red.), Wartości w pedagogice. Wolność, odpowiedzialność, godność. Rzeszów: Wydawnictwo Uniwersytetu Rzeszowskiego.

Gajda, J. (2013). Wartości w życiu i edukacji człowieka. Toruń: Wydawnictwo Adam Marszałek.

Grzegorczyk, A. (1983). Pojęcie godności jako element poznawczej regulacji ludzkiego zachowania. Studia Filozoficzne, nr 8-9.

Hołub, G. (2014). Osoba w labiryncie decyzji moralnych. Bioetyka w perspektywie personalistycznej. Kraków: Wydawnictwo św. Stanisława BM. 


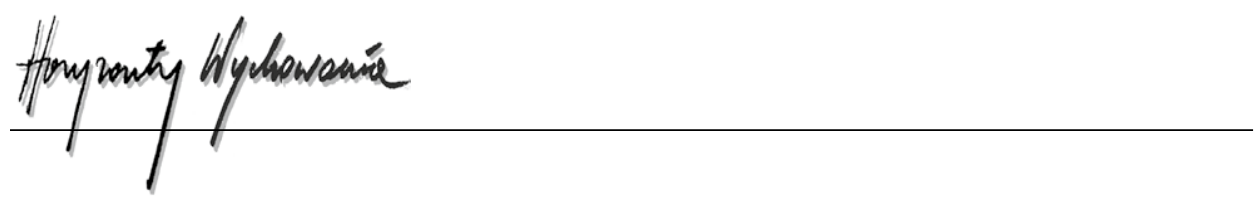

Kanclerz, B. (2015). Orientacje życiowe młodzieży akademickiej. Poznań: Wydawnictwo Naukowe Uniwersytetu im. Adama Mickiewicza.

Konarska, J. (2003). Zmiana wartości czy moralności? (niesprawność nabyta). Mysłowice: Górnośląska Wyższa Szkoła Pedagogiczna imienia Kardynała Augusta Hlonda w Mysłowicach.

Kozielecki, J. (1977). O godności człowieka. Warszawa: Czytelnik.

Mariański, J. (2014). Godność - wartość uniwersalna i relatywna. W: Janusz Mariański. Moralność w kontekście społecznym. Kraków: Zakład Wydawniczy NOMOS.

Mikrut, A. (2013). O poszanowaniu godności osób niepełnosprawnych - idea a rzeczywistość. Pieleggniarstwo i Zdrowie Publiczne, nr 3-4.

Mikrut, A. (2014). O odkrywaniu swojej godności przez osoby z niepełnosprawnością intelektualną. Annales Universitatis Mariae Curie-Skłodowska, 27, nr 1.

Mikrut, A. (2016). O promowaniu godności człowieka w ramach konwencji o prawach osób niepełnosprawnych. Rocznik Komisji Nauk Pedagogicznych, 69.

Nowicka-Kozioł, M. (2002). Godność podmiotu ponowoczesnego. W: Prawo głosu i różnicy a podmiotowość. Warszawa: Wydawnictwo Akademii Pedagogiki Specjalnej im. Marii Grzegorzewskiej.

Oleś, P.K. (2012). Godność - zapoznana czy zapoznawana? W: H. Grzmil-Tylutki i Z. Mirek (red.), Godność w perspektywie nauk. Kraków: Międzynarodowe Towarzystwo Naukowe Fides et Ratio.

Ossowska, M. (1983). O człowieku, moralności i nauce. Miscellanea. Warszawa: Państwowe Wydawnictwo Naukowe.

Ostrowska, U. (2004). Studenci wobec godności. Między nieodzownością a kontestacją. Kraków: Oficyna Wydawnicza „Impuls”.

Pasteczko, E. (2012). Młodzież o godności człowieka a nauczanie Jana Pawła II. W: H. Grzmil-Tylutki i Z. Mirek (red.), Godność w perspektywie nauk. Kraków: Międzynarodowe Towarzystwo Naukowe Fides et Ratio.

Piluś, H. (1999). Godność osobowa jako podstawa i uzasadnienie niezbywalnych praw i wolności człowieka. W: R. Rosa (red.), Prawa i wolności człowieka w edukacji demokratycznego państwa. Materiały I Ogólnopolskiej Konferencji Naukowej Siedlce - Chlewiska 7-8 grudnia 1999 r. Siedlce: Wydawnictwo Uczelniane Akademii Podlaskiej.

Prüfer, P. (2017). Godnościowy wysiłek człowieka w ocalaniu własnej godności. Refleksje wokół książki Janusza Mariańskiego. W: P. Prüfer (red.), Człowiek sam dla siebie wyzwaniem. Gorzów Wielkopolski: Akademia im. Jakuba z Paradyża w Gorzowie Wielkopolskim.

Rynio, A. (2019). Wychowanie do odpowiedzialności. Studium teorii i praktyki pedagogiki integralnej. Lublin: Wydawnictwo KUL.

Stępień, S. (2016). Godność osobowa. W: K. Chałas i A. Maj (red.), Encyklopedia aksjologii pedagogicznej. Radom: POLWEN Polskie Wydawnictwo Encyklopedyczne.

\section{Copyright and License}

This article is published under the terms of the Creative Commons Attribution - NoDerivs (CC BY- ND 4.0) License http://creativecommons.org/licenses/by-nd/4.0/ 